Revista de la red interuniversitaria de estudios sobre las literaturas rioplatenses contemporáneas en Francia

$10 \mid 2014$

El XIX en el XX

\title{
“Poema al Torito", de La virgen cabeza (2009)
}

\section{Gabriela Cabezón Cámara}

URL: http://journals.openedition.org/lirico/1695

DOI: $10.4000 /$ lirico.1695

ISSN: 2262-8339

Editor

Réseau interuniversitaire d'étude des littératures contemporaines du Río de la Plata

Referencia electrónica

Gabriela Cabezón Cámara, "Poema al Torito", de La virgen cabeza (2009)», Cuadernos LIRICO [En

línea], 10 | 2014, Puesto en línea el 15 marzo 2014, consultado el 20 abril 2019. URL : http:// journals.openedition.org/lirico/1695; DOI : 10.4000/lirico.1695

Este documento fue generado automáticamente el 20 abril 2019.

\section{c.) (i) (2)}

Cuadernos LIRICO está distribuido bajo una Licencia Creative Commons Atribución-NoComercialSinDerivar 4.0 Internacional. 


\section{"Poema al Torito", de La virgen cabeza (2009)}

\section{Gabriela Cabezón Cámara}

Dale la mano al fatigado ingenio Amor, y al frágil y cansado estilo, para cantar a aquella que se ha vuelto inmortal ciudadana de los cielos ¿inmortal y ciudadana? ¿era Evita la finada? ¿la poesía es de Perón? ¿of the first trabajador? No, de Petrarca y era al aura, al laurel. A su Laura in the vergel le cantaba azul un ala, I love you y ajerejé, al compás de la vigüela ahí se ponía a remembrar ella era onda la Gioconda and she was, ella re-was y no sólo como Troya. Vengo a cantarle a Magoya qué pasó con el Torito : lo encontramos de chiquito en el medio de la villa $\mathrm{y}$ fue for ever and ever que se quedó en la familia. De gauchos guachos rellena está la pampa asesina : nobody que los proteja y wiyhout dog que los ladre 
andan las guaguas sin padre como anduvieron before los babies de Agamenón: ¿Cómo podré dirigir las plegarias to my father? ¿Diré que vengo acaso a ofrecerlas al esposo en el nombre de la Virgen, lo que es decir mi madre? Eran otras las orfandades las de los crazys atridas para el Torito la vida from beginning to the end fue siempre una res jodida y lo hicieron fenecer en un cayo de Florida. El puto american dream, fue la muerte para él : le cortaron la garganta a refalosa y tin tin. El forense de latinos de la Miami Police pensó en un psycho-argentino : diz que le oyeron decir que es costumbre nacional esa forma de matar $y$ que tenemos un baile, que danzan hasta los frailes the dance of la refalosa, y la cantamos así :

"abajito de la oreja. con un puñal bien templao que se llama el quitapenas, le atravesamos las venas del pescuezo.

¿Y qué se le hace con eso? larga sangre que es un gusto, y del susto entra a revolver los ojos". Ese fucking policía doesn't know romancería : si supiera él pensaría que el killer was español o judío sefaradí, un chileno o un mexicano, ellos cantaban así : "Por regalo de mi vuelta te he de dar rico vestir, 
vestido de fina grana

forrado de carmesí,

y gargantilla encarnada

como en damas nunca vi ;

gargantilla de mi espada,

que tu cuello va a ceñir".

$¿$ ¿ el Torito se fue al cielo

con la Laura de Petrarca?

Se fue, seguro que sí

Pero el check-in fue un desastre

porque alguien lo degolló

para verlo refalar

¡en la sangre!

hasta que le dio un calambre

y se cayó a patalear.

Después fue fiambre :

¡Oh limitada jornada,

oh frágil naturaleza !

Hoy is born la tierna flor

y hoy mismo her way termina ;

todo a la muerte se enfila,

va a parar al asador

cada bicho que camina.

Acá yerto el matador,

acá está el amigo muerto

acá el cuerpo ceniciento

como restos de un almuerzo.

Nos venía a visitar

con latitas de caviar

que afanaba en Recoleta,

todo el día con champán

pagado por ladys chetas

que colgaban con pasión

de su hot neck de animal

que ahora yace fileteado

en la morgue judicial :

la muerte es siempre temprana

y no perdona a ninguno.

Dice Cleopatra que dice

la que aplastó a Satanás

que igual se murió el Bautista

$\mathrm{y}$ toda una larga lista

diz que elegidos del Lord

$\mathrm{y}$ creemos que al señor

le da por sacar de villas

a los que quiere llevar

a gozar sus maravillas.

Suelen decir nuestros niños, 
desde la más tierna edá:

we that are young

shall never see so much

nor live so long.

Aunque atemos a la suerte,

No nos salva ni el destierro,

es super fast nuestra muerte :

nadie llega a los cincuenta

siempre hay bala o puñalada

transformándonos en tierra,

humo, polvo, sombra, nada. 